\title{
Omega-6/omega-3 ratio serum, omega-3 index, and hs-CRP serum in obese adolescents aged 16-18 years
}

\author{
${ }^{1}$ Mahesty, I.R., ${ }^{1}$ Sulchan, M. and ${ }^{2}$ Kartini, A. \\ ${ }^{1}$ Department of Nutrition Science, Faculty of Medicine, Diponegoro University, Semarang, Indonesia \\ ${ }^{2}$ Department of Public Health Nutrition, Faculty of Public Health, Diponegoro University, Semarang, \\ Indonesia
}

\author{
Article history: \\ Received: 31 January 2020 \\ Received in revised form: 10 \\ April 2020 \\ Accepted: 5 June 2020 \\ Available Online: 8 June \\ 2020
}

\section{Keywords:}

Omega-6/Omega-3 ratio,

Omega-6,

Omega-3,

Omega-3 index,

hs-CRP

\section{DOI:}

https://doi.org/10.26656/fr.2017.4(S3).S28

\begin{abstract}
The incidence of obesity in the world has more than tripled between 1975 and 2016. International organizations and many researchers continue to look for causes of obesity. The expected increase in income ratio with an increase in the ratio of omega-6/omega-3 intake from 1:1 to 20:1 in the last three decades. This study aimed to describe the ratio of serum omega-6/omega-3, omega-3 index, and serum hs-CRP in obese adolescents aged 16 -18 years. This research used cross-sectional study design with a total of thirty-two subjects. Omega-6 serum, omega-3 serum, and omega-3 index were analyzed using gas chromatography while serum hs-CRP was analyzed using Turbidimetric Assay. The mean of omega- 6 serum was $3358.59 \pm 845.75 \mu \mathrm{mol} / \mathrm{L}$, omega-3 serum was $281.00 \pm 81.25 \mu \mathrm{mol} /$ L, $62.5 \%$ of subjects had omega-3 index levels $<4 \%$ (below standard), and $93.8 \%$ of subjects had a serum omega-6/omega-3 ratio $>9: 1$ (above standard). As many as $25 \%$ of subjects had serum hs-CRP levels $>3 \mathrm{mg} / \mathrm{L}$. These findings suggested that $93.8 \%$ of subjects had high omega-6/omega- 3 ratio serum and $25 \%$ of subjects had hs-CRP serum $>$ $3 \mathrm{mg} / \mathrm{L}$.
\end{abstract}

\section{Introduction}

The incidence of obesity in the world has more than tripled between 1975 and 2016. According to the World Health Organization (WHO) data, the prevalence of overweight and obesity among adolescents increased from only $4 \%$ in 1975 to more than $18 \%$ in 2016 (WHO, 2017). Obesity does not only occur in developed countries but also occurs in developing countries such as Southeast Asia and Africa (WHO, 2015). In Indonesia, the prevalence of obesity among adolescents shows quite alarming figures. In 2010, as many as $1.4 \%$ of adolescents were obese and in 2013 increased to 7.3\% (Balitbang Kemenkes RI, 2010, 2013).

Obesity is a condition where there is an excessive fat accumulation in adipose tissue (McPhee et al., 2011). Someone who is obese in their teens will tend to be obese in adulthood and the elderly. Obesity has a negative impact on health that can cause metabolic syndrome. Metabolic syndrome is a collection of risk factors for cardiovascular disease and diabetes mellitus. The main components of metabolic syndrome are abdominal obesity, insulin resistance, dyslipidemia, and hypertension (Wardlaw et al., 2007).
International organizations and many scientists continue to look for causes of obesity. Quoting the laws of thermodynamics, scientists not only interpret the concept of "calories are calories", but the source of calories also affects human metabolism and appetite. For example, calories from omega-6-rich vegetable oils are pro-inflammatory and thrombogenic, whereas calories from omega-3-rich fish are anti-inflammatory and antithrombogenic (Simopoulos et al., 2016).

Omega- 6 and omega-3 are essential fatty acids that can only be obtained from food and cannot be processed by the body because of mammals, including humans, lack enzymes for desaturation namely $\Delta 12$ and $\Delta 15$. Omega- 6 and omega-3 are precursors for lipid mediators called eicosanoids. In general, eicosanoids obtained from omega- 6 are pro-inflammatory which can increase the value of chronic systemic inflammation biomarkers, such as C-reactive protein (CRP). Omega-6 and omega-3 were also known to have different roles in the development of obesity through the mechanism of adipogenesis, lipid homeostasis, Brain-Gut-Adipose tissue axis and systemic inflammation (Fan et al., 2011; Monk et al., 2012).

In the last three decades, it was known that omega-6 intake continues to increase and omega-3 intake 
continues to decrease resulting in a large increase in the omega-6/omega-3 ratio of $1: 1$ during the evolutionary period to reach 20:1 at this time or even higher again. This change in fatty acid composition was in line with the increase in the prevalence of overweight and obesity in the world. The increase in omega- 6 was known to be caused by modern agriculture and aquaculture which is replacing animal feed from wild grasses into grains that were rich in omega-6. Research on the ratio of omega-6/ omega-3 to obesity was still limited, especially the assessment was only based on the use of a food intake frequency questionnaire (FFQ) not using a blood test. This study aimed to describe the ratio of serum omega-6/ omega-3 fatty acid, omega- 3 fatty acid index, and serum hs-CRP in obese adolescents aged 16-18 years.

\section{Materials and methods}

A descriptive study with a cross sectional study design was conducted at SMAN 9 and SMKN 11 Semarang, Indonesia. This location was chosen based on the highest obesity prevalence in the city of Semarang from the data collected from the schoolchildren. The study population was adolescents aged 16-18 years studying in high school 9 Semarang and SMKN 11. The total subjects in this study were thirty-two people.

The research location was taken using the multistage random sampling technique and the research subjects were taken by proportional random sampling technique to meet the inclusion and exclusion criteria. The inclusion criteria of this study were adolescents aged 1618 years who were obese with an indicator of body mass index per age $>2 \mathrm{SD}$, did not take omega- 6 supplements or omega-3 supplements, were willing to be a research sample by filling out informed consent. The research ethics was approved by the Sultan Agung Islamic University's Faculty of Medicine.

The study was implemented by screening the nutritional status of the students at the study site.
Selected subjects were determined and asked for consent. Once approval of consent was received, data collection of the subject using questionnaires of food intake interviews with Semi-Quantitative Food Frequency Questionnaires (SQ-FFQ) and physical activity with Physical activity level (PAL) questionnaire. Blood samples were collected from subjects to examine the serum omega-6, omega-3, omega-3 index and serum hsCRP by health analysts from Prodia. The Z-score of the anthropometric data was calculated data using WHO Anthro Plus application. Data analysis using SPSS 16 application. Normality of data distribution was done by Saphiro-Wilk test. Univariate data analysis was performed by displaying data descriptively.

\section{Results}

\subsection{Screening}

The results of the screening carried out on 831 adolescents at SMAN 9 and at SMKN 11 Semarang, Indonesia showed that 110 adolescents $(13.2 \%)$ were overweight and 75 adolescents $(9.02 \%)$ were obese. As many as $53.3 \%$ of obese adolescents were 16 years old and $61.3 \%$ of obese adolescents were male. Obese adolescents were randomly selected from various majors and classes, so as many as 32 research subjects were obtained. Of the 32 students selected, $75 \%$ (24 people) were male and $25 \%$ ( 8 people) were female. General description of the characteristics of obese adolescents aged 16-18 can be seen in Table 1. Table 1 shows the characteristics of subjects consisting of gender, BMI, serum omega- 6 fatty acids, serum omega- 3 fatty acids, omega-3 fatty acid index, serum omega-6/omega-3 fatty acid ratios, serum hs-CRP and intake. A description of serum omega- 6 and omega-3 fatty acids in obese adolescents can be seen in Table 2.

\subsection{Omega-6 serum}

Table 2 shows the depictions of serum omega- 6 and omega- 3 in obese adolescents. The measurement results

Table 1. General description of the characteristics of obese adolescents aged 16-18

\begin{tabular}{|c|c|c|c|c|}
\hline Variable & $\mathrm{F}$ & $\%$ & Mean \pm SD & Median $(\min -\max )$ \\
\hline \multicolumn{5}{|l|}{ Sex } \\
\hline Male & 24 & 75 & & \\
\hline Female & 8 & 25 & & \\
\hline BMI & & & $2.51 \pm 0.46$ & $2.40(2.03-3.8)$ \\
\hline Omega-6 Serum $(\mu \mathrm{mol} / \mathrm{L})$ & & & $3358.59 \pm 845.75$ & $3231.5(2021-5329)$ \\
\hline Omega-3 Serum $(\mu \mathrm{mol} / \mathrm{L})$ & & & $281.00 \pm 81.25$ & $264.5(164-475)$ \\
\hline Omega-3 Index (\%) & & & $3.47 \pm 0.80$ & $3(2-6)$ \\
\hline Omega-6/Omega-3 Ratio Serum & & & $12.28 \pm 2.32$ & $12(7.6-19.1)$ \\
\hline hs-CRP Serum (mg/L) & & & $2.60 \pm 3,49$ & $1.15(0.2-14.4)$ \\
\hline Omega-6 Intake (g) & & & $18 \pm 9.7$ & $17.1(3.7-55.4)$ \\
\hline Omega-3 Intake (g) & & & $0.387 \pm 0.25$ & $0.25(0.0-2.3)$ \\
\hline Omega-6/Omega-3 Ratio Intake & & & $63.9 \pm 73.75$ & $32.85(6.1-283)$ \\
\hline
\end{tabular}


showed $87.5 \%$ of the total subjects had omega- 6 serums in the normal category and the other $9.4 \%$ had high omega- 6 serums. Omega- 6 serum was analyzed from the amount of LA + GLA + DGLA + AA in the blood. A high omega- 6 serum can be caused by increased intake of omega- 6 sources that were consumed daily. The results of the calculation of omega- 6 intake in this study showed that $71.9 \%$ of the total subjects had omega- 6 intake exceeding the nutritional adequacy rate. Most subjects consume processed soybeans such as tofu and tempeh to reach $200 \mathrm{~g} /$ day and consume palm oil more than $30 \mathrm{~g} /$ day which is a source of omega- 6 .

Table 2. Description of serum omega-6 and omega-3 in obese adolescents

\begin{tabular}{lcccc}
\hline \multirow{2}{*}{ Serum } & \multicolumn{3}{c}{ Category } & \multirow{2}{*}{ Total } \\
\cline { 2 - 4 } & Low & Normal & High & \\
\hline Omega-6 & $1(3.1 \%)$ & $28(87.5 \%)$ & $3(9.4 \%)$ & $24(100 \%)$ \\
Omega-3 & $6(18.7 \%)$ & $26(81.2 \%)$ & $0(0 \%)$ & $8(100 \%)$ \\
\hline
\end{tabular}

\subsection{Omega-3 serum}

The measurement results also showed $81.2 \%$ of the total subjects had serum omega-3 in the normal category and another $18.7 \%$ had omega-3 fatty acids in the low category. The low omega- 3 serum can be caused by a lack of daily intake of omega- 3 sources. The results of the calculation of omega- 3 intake in this study showed that $96.8 \%$ of the total subjects had omega- 3 intake less than the nutritional adequacy rate. Omega-3 serum is analyzed from the amount of ALA + EPA + DHA in the blood. A description of the omega- 3 index can be seen in Table 3.

Table 3. Description of omega-3 index in obese adolescents

\begin{tabular}{ccc}
\hline \multicolumn{2}{c}{ Omega-3 Index } & Total \\
\hline$<4 \%$ & $4-8 \%$ & \\
\hline $20(62.5 \%)$ & $12(37.5 \%)$ & $32(100 \%)$ \\
\hline
\end{tabular}

\subsection{Omega-3 index}

Table 3 shows the description of the omega- 3 index in obese adolescents. The results showed that $62.5 \%$ of the total research subjects had an omega-3 index $<4 \%$ which was included in the low category. The omega-3 index was analyzed based on the amount of EPA and DHA in the blood.

\subsection{Omega-6/Omega-3 ratio serum}

A description of serum omega-6/omega-3 ratio serum can be seen in Table 4 . Table 4 shows description serum omega-6/omega-3 ratio in obese adolescents. Based on Table 4, 93.8\% of the total subjects had a high omega-6/omega-3 fatty acid ratio in the high category ( $>$ 9: 1).
Table 4. Description of serum omega-6/omega-3 ratio in obese adolescents

\begin{tabular}{ccccc}
\hline \multicolumn{4}{c}{ Omega-6/Omega-3 Ratio } & \multirow{2}{*}{ Total } \\
\cline { 1 - 4 } Elevated & Desirable & Intermediate & Undesirable \\
\hline $0(0 \%)$ & $0(0 \%)$ & $2(6.2 \%)$ & $30(93.8 \%)$ & $32(100 \%)$ \\
\hline
\end{tabular}

\section{6 hs-CRP serum}

The description of serum hs-CRP in obese adolescents can be seen in Table 5 . Table 5 shows the depiction of serum hs-CRP in obese adolescents. The results showed $75 \%$ of the total subjects at risk of cardiovascular disease with low-risk criteria of $21.8 \%$, moderate risk of $28.1 \%$ and high risk of $25 \%$.

Table 5. Description of hs-CRP Serum in obesity adolescents

\begin{tabular}{lcccc}
\hline \multicolumn{4}{c}{ hs-CRP Serum } & \multirow{2}{*}{ Total } \\
\cline { 1 - 4 } No Risk & Low Risk & Moderate Risk & High Risk & \\
\hline $8(25 \%)$ & $7(21.8 \%)$ & $9(28.1 \%)$ & $8(25 \%)$ & $32(100 \%)$ \\
\hline
\end{tabular}

\section{Discussion}

In the last three decades, it is known that the intake of omega- 6 fatty acids continues to increase and the intake of omega- 3 continues to decline to result in a large increase in the ratio of omega-6/omega-3 from 1:1 during the evolutionary period to $20: 1$ at this time or even higher. This change in fatty acid composition is in line with the increase in the prevalence of overweight and obesity in the world. This phenomenon is also in accordance with the results of this study, where the ratio of omega-6/omega-3 intake with the highest value in obese adolescents reaches 283:1 (Table 1).

The measurement results showed $87.5 \%$ of the total subjects had omega- 6 serums in the normal category and the other $9.4 \%$ had high omega- 6 fatty acid serums. The results of the calculation of omega- 6 intake in this study showed that $71.9 \%$ of the total subjects had omega- 6 intake exceeding the nutritional adequacy rate. Most subjects consume processed soybeans such as tofu and tempeh to reach $200 \mathrm{~g} /$ day and consume palm oil more than $30 \mathrm{~g} /$ day. The measurement results also showed $81.2 \%$ of the total subjects had serum omega- 3 in the normal category and another $18.7 \%$ had omega- 3 in the low category.

The standard omega-3 index in the blood is $4 \%$ (Harris et al., 2004). The low omega-3 index in this study is in line with the results of FFQ measurements which show that almost all subjects consume less fish and seafood which is the source of omega-3. Research results from the Statistics Agency of the Ministry of Maritime Affairs and Fisheries in 2018 also stated that the people of Central Java were listed as the secondlowest consuming fish population in Indonesia, 
amounting to $25.26 \mathrm{~kg} / \mathrm{capita} /$ year (Kementerian Kelautan dan Perikanan Republik Indonesia, 2019).

The ratio of serum omega-6/omega- 3 was analyzed from the number of comparisons between total levels of omega- 6 and total levels of omega- 3 in the blood. The serum omega-6/omega-3 ratio is divided into 4 categories: elevated if the ratio $<3: 1$, desirable if the ratio is $3: 1-5: 1$, intermediate if the ratio is $5: 1-9: 1$, and undesirable if the ratio $>$ 9:1 (Harris and Von Schacky, 2004).

The results showed $75 \%$ of the total subjects at risk of cardiovascular disease. C-reactive protein is an acute phase marker protein as part of the innate immunity produced by the liver, can be used as a strong marker of inflammation in the body both in adults, adolescents, and children (Libby et al., 2002; Soriano-Guillen, 2008).

Omega-6 and omega-3 go through the same metabolic process, namely elongation and desaturation. This same process triggers competition between omega- 6 and omega-3. Both of them competed in the desaturation process of desaturase 1 fatty acid enzymes (FADS1) and desaturase 2 fatty acids (FADS2). In a research note, there are several important genetic variables in fatty acid biosynthesis, namely FADS A and FADS D. Haplotype $\mathrm{D}$ is known to be associated with higher blood lipid levels compared to someone who has haplotype A (Mathias et al., 2011; Sergeant et al., 2012).

The ratio of omega- 6 and omega- 3 plays an important role in the development of obesity through the mechanism of gene expression in adipogenesis, lipid homeostasis, Brain-Gut-Adipose tissue axis and systemic inflammation (Fan et al., 2011; Monk et al., 2012). Omega-6 and omega-3 have opposite effects in these mechanisms. Omega-6 and omega-3 can function as transcription factors to regulate the expression of genes involved in pre-adipocyte differentiation.

In the initial step of pre-adipocyte differentiation, AA metabolites from omega-6 by Cyclooxygenase (COX) activate the protein kinase A (PKA) pathway that regulates the expression of the peroxisome proliferatorsactivated receptor family (PPAR) that leads to adipogenesis. The next step, AA by lipoxygenase (LOX) also activates the expression of PPARs that leads to adipogenesis (Wang et al., 2016).

Omega-3 also modulate lipid homeostasis by suppressing the expression of genes involved in lipogenesis including fatty acid synthase (FAS), lipoprotein lipase (LPL) and stearoyl-CoA desaturase-I (SCD-I) as well as increasing the expression of genes involved in $\beta$ fatty acids -oxidase such as acetyl-CoA oxidase (ACOX). The end result, namely the reduction of accumulation of body fat, especially in the liver and skeletal muscle as well as in adipose tissue (Wang et al., 2016).

Another mechanism of omega-6 and omega-3 in influencing body fat is through the Brain-Gut-Adipose tissue axis. First, omega- 6 increase endocannabinoid production which functions as a control center for appetite and energy balance. Increased endocannabinoid receptors will stimulate food intake and lipogenesis in the liver. Meanwhile, omega-3 can reduce endocannabinoid production and decrease the sensitivity of the receptor associated (Batetta et al., 2009). In addition, DHA can induce anorexigenic neuropeptide proopimelanocortin in the hypothalamus which limits appetite and leads to weight loss.

Second, omega- 6 and omega- 3 fatty acids can affect the leptin signaling pathway differently. Leptin is a peptide hormone that is coded by the ob gene and is produced and secreted by adipose tissue. The main function of leptin is as a regulator of body weight by affecting appetite and energy expenditure. Omega- 6 is known to increase leptin production while omega-3 is known to reduce leptin production and leptin receptors (Fan et al., 2011).

Third, omega- 6 and omega-3 regulate adiponectin expression and secretion differently. Adiponectin is a plasma protein that is produced and secreted exclusively by adipocytes. Adiponectin suppresses a number of pathological processes associated with obesity. Omega-6 are known to reduce the production of adiponectin while omega-3 is known to increase adiponectin production (An et al., 2011).

Wang et al. (2016) showed that the ratio of omega-6/ omega-3 had a significant relationship with the incidence of obesity. The study also showed that among 534 women who had a normal BMI, 186 of them became overweight or obese for an average of 10.4 years later due to an increased ratio of omega-6/omega-3 (Wang et al., 2016).

Omega-6 and omega-3 are precursors for lipid mediators called eicosanoids. In general, eicosanoids obtained from omega- 6 are pro-inflammatory which can increase the value of chronic systemic inflammatory biomarkers, such as CRP (Blasbalg et al., 2011). Series 2 prostaglandins (PGE2, PGI2, and TXA2) and series 4 leukotrienes (LTB4) derived from omega-6 are proinflammatory compounds. In contrast, series 3 prostaglandins (PGE3, PGI3, and TXA3) and series 5 leukotrienes (LTB5) derived from omega-3 are antiinflammatory. Because omega- 6 and omega- 3 compete directly to use the same conversion enzyme, the status of 
inflammation depends on the amount of omega- 6 and omega-3 in the body (Monk et al., 2012).

\section{Conclusion}

In conclusion, $93.8 \%$ of subjects had an omega- $6 /$ omega-3 ratio $>9: 1$ (above standard), $62.5 \%$ of subjects had an omega-3 index $<4 \%$ (below standard), and $25 \%$ of adolescent male and female had serum levels of hsCRP $>3 \mathrm{mg} / \mathrm{L}$. The research suggested to balance the food intake from omega- 6 and omega- 3 sources to maintain health and as an effort to prevent obesity.

\section{References}

An, W.S., Son, Y.K., Kim, S.E., Kim, K.H., Bae, H.R., Lee, S. and Vaziri, N.D. (2011). Association of adiponectin and leptin with serum lipids and erythrocyte omega-3 and omega- 6 fatty acids in dialysis patients. Clinical Nephrology, 75, 195-203. https://doi.org/10.5414/CNP75195

Balitbang Kemenkes RI. (2010). Riset Kesehatan Dasar. Jakarta, Indonesia: Balitbang Kemenkes RI.

Balitbang Kemenkes RI. (2013). Riset Kesehatan Dasar; RISKESDAS. Jakarta, Indonesia: Balitbang Kemenkes RI.

Batetta, B., Griinari, M., Carta, G., Murru, E., Ligresti, A., Cordeddu, L., Giordano, E., Sanna, F., Bisogno, T., Uda, S., Collu, M., Bruheim, I., Marzo, V.D. and Banni, S. (2009). Endocannabinoids may mediate the ability of (n-3) fatty acids to reduce ectopic fat and inflammatory mediators in obese Zucker rats. Journal of Nutrition, 139(8), 1495-1501. https:// doi.org/10.3945/jn.109.104844

Blasbalg, T.L., Hibbeln, J.R., Ramsden, C.E., Majchrzak, S.F. and Rawlings, R.R. (2011). Changes in consumption of omega-3 and omega- 6 fatty acids in the United States during the 20th century. American Journal of Clinical Nutrition, 93(5), 950962. https://doi.org/10.3945/ajcn.110.006643

Fan, C., Liu, X., S. W., Deckelbaum, R.J. and Qi, K. (2011). The Regulation of Leptin, Leptin Receptor and Pro-opiomelanocortin Expression by N-3 PUFAs in Diet-Induced Obese Mice Is Not Related to the Methylation of Their Promoters. Nutrition and Metabolism, 8, 31 https://doi.org/10.1186/1743-7075 $-8-31$

Harris, W.S. and Von Schacky, C.M.D. (2004). The Omega-3 Index: a new risk factor for death from coronary heart disease? Preventive Medicine, 39(1), 212-220. https://doi.org/10.1016/ j.ypmed.2004.02.030

Kementerian Kelautan dan Perikanan Republik Indonesia. Permasalahan Konsumsi dan Manfaat
Ikan. Retrieved 14 July, 2019 Kementerian Kelautan dan Perikanan Republik Indonesia website from: https// kkp.go.id/artikel/2638-faq-permasalahankonsumsi-dan-manfaat-ikan. [In Bahasa Indonesia].

Libby, P., Ridker, P.M. and Maseri, A. (2002). Inflammation and atherosclerosis. Circulation, 105, 1135-1143. https://doi.org/10.1161/hc0902.104353

Mathias, R.A., Sergeant, S., Ruczinski, I., Torgerson, D.G., Hugenschmidt, C.E., Kubala, M., Vaidya, D., Suktitipat, B., Ziegler, J.T., Ivester, P., Case, D., Yanek, L.R., Freedman, B.I., Rudock, M.E., Barnes, K.C., Langefeld, C.D., Becker, L.C., Bowden, D.W., Becker, D.M. and Chilton, F.H. (2011). The impact of FADS genetic variants on $n 6$ polyunsaturated fatty acid metabolism in African Americans. BMC Genetics, 12, 50. https:// doi.org/10.1186/1471-2156-12-50

McPhee, S.J., Ganong and William, F. (2011). Patofisiologi Penyakit: Pengantar Menuju Kedokteran Klinis. Jakarta, Indonesia: EGC. [In Bahasa Indonesia].

Monk, J.M., Hou, T.Y., Turk, H.F., Weeks, B., Wu, C., McMurray, D.N. and Chapkin, R.S. (2012). Dietary n-3 polyunsaturated fatty acids (PUFA) decrease obesity-associated Th17 cell-mediated inflammation during colitis. PLoS One, 7, e49739. https:// doi.org/10.1371/journal.pone.0049739

Sergeant, S., Hugenschmidt, C.E., Rudock, M.E., Ziegler, J.T., Ivester, P., Ainsworth, H.C. Vaidya, D., Case, L.D., Langefeld, C.D., Freedman, B.I., Bowden, D.W., Mathias, R.A. and Chilton, F.H. (2012). Differences in arachidonic acid levels and fatty acid desaturase (FADS) gene variants in African Americans and European Americans with diabetes or the metabolic syndrome. British Journal of Nutrition, 107, 547-555. https://doi.org/10.1017/ S0007114511003230

Simopoulos, A.P. and DiNicolantonio, J.J. (2016). The importance of a balanced $\omega-6$ to $\omega-3$ ratio in the prevention and management of obesity. Open Heart, 3(2), e000385. https://doi.org/10.1136/openhrt-2015000385

Soriano-Guillen, L., Barbara, H.-G., Pita, J., DominguezGarrido, N., Rio-Camacho, G.D. and Rovira, A. (2008). High-sensitivity C-reactive protein is a good marker of cardiovascular risk in obese children and adolescents. European Journal of Endocrinology, 159(1), 1-4. https://doi.org/10.1530/EJE-08-0212

Wang, L., Manson, J.E., Rautiainen, S., Gaziano, J.M., Buring, J.E., Tsai, M.Y. and Sesso, H.D. (2016). A prospective study of erythrocyte polyunsaturated fatty acid, weight gain, and risk of becoming overweight or obese in middle-aged and older 
women. European Journal of Nutrition, 55(2), 687697. https://doi.org/10.1007/s00394-015-0889-y

Wardlaw, G.M. and Hampl, J.S. (2007). Perspective in Nutrition. $7^{\text {th }}$ ed. NewYork: McGraw-Hill.

WHO. (2015). World Health Organization (WHO). Global Report. Switzerland: WHO.

WHO. (2017). Obesity and overweight. Retreived from WHO website: www. who.int /news-room /factsheets/detail/obesity-and-overweight 